\title{
Aspirin Potentiates Prestimulated Acid Secretion and Mobilizes Intracellular Calcium in Rabbit Parietal Cells
}

Robert A. Levine, Jyotirmoy Nandi, and Rebecca L. King

Department of Medicine, State University of New York Health Science Center at Syracuse, Syracuse, New York 13210

\begin{abstract}
The effects of aspirin on gastric acid secretion were studied in isolated rabbit parietal cells (PC). Aspirin $\left(1^{-5} \mathrm{M}\right)$ potentiated histamine-, dibutyryl cyclic AMP (dbcAMP)-, forskolin- and 3-isobutyl-1-methylxanthine-stimulated acid secretion without affecting basal acid secretion. Augmentation of secretagogue-stimulated acid secretion by aspirin was dependent on calcium $\left(\mathrm{Ca}^{2+}\right)$ since potentiation was blocked by removal of extracellular $\mathrm{Ca}^{2+}\left(\left[\mathrm{Ca}^{2+}\right]_{0}\right)$ or addition of the calcium antagonist lanthanum chloride. Using the $\mathrm{Ca}^{2+}$ probe fura-2, aspirin $\left(10^{-6}-2 \times 10^{-5} \mathrm{M}\right)$ rapidly increased intracellular free $\mathrm{Ca}^{2+}$ concentration $\left(\left[\mathrm{Ca}^{2+}\right]_{i}\right)$ in a dose-dependent manner. The source of released $\mathrm{Ca}^{2+}$ was intracellular as demonstrated by depletion of intracellular $\mathrm{Ca}^{2+}$ and $\left[\mathrm{Ca}^{2+}\right]_{0}$ with EGTA washing. Aspirin did not affect several other signal transduction sites involved in stimulus-secretion coupling, including the $\mathrm{H}_{2}$ receptor, intracellular cyclic AMP (cAMP), inositol 1,4,5, triphosphate $\left(\mathrm{IP}_{3}\right)$ and $\mathrm{H}^{+}, \mathrm{K}^{+}$-ATPase. Aspirin decreased PC prostaglandin $\mathrm{E}_{2}\left(\mathrm{PGE}_{2}\right)$ content by $98 \%$. Exogenous dimethyl $\mathrm{PGE}_{2}\left(\mathrm{dmPGE}_{2}\right)$ inhibited both histamine-stimulated acid secretion and its enhancement by aspirin. In contrast, dmPGE abolished aspirin-induced potentiation of dbcAMP-stimulated acid secretion by augmenting the dbcAMP-stimulated response. These results indicate that aspirin acts at a site beyond the adenylate cyclase/cAMP system and before the proton pump, presumably by releasing $\mathrm{Ca}^{2+}$ from an $\mathrm{IP}_{3}$-independent intracellular storage pool and by inhibiting $\mathrm{PGE}_{2}$ generation. (J. Clin. Invest. 1990. 86:400-408.) Key words: secretagogues - inositol triphosphate - cyclic AMP - $\mathrm{PGE}_{2} \cdot$ lanthanum
\end{abstract}

\section{Introduction}

Aspirin, the most commonly used of all drugs, is widely employed in the treatment of musculoskeletal diseases and as prophylaxis for coronary artery disease. Despite the high incidence of aspirin-induced gastric mucosal damage $(1,2)$ and the increased risk of complications from existing ulcers in patients

Presented in part at the 1987, 1988, and 1989 Annual Meetings of the American Gastroenterological Association and has appeared in abstract form (1987. Gastroenterology. 92:1505; 1988. Gastroenterology. 94:260; and 1989. Gastroenterology. 95:297).

Address reprint requests to Dr. Levine, Section of Gastroenterology, Department of Medicine, University Hospital, 750 East Adams Street, Syracuse, NY 13210.

Received for publication 17 November 1989 and in revised form 16 March 1990.

J. Clin. Invest.

(C) The American Society for Clinical Investigation, Inc.

$0021-9738 / 90 / 08 / 0400 / 09 \$ 2.00$

Volume 86, August 1990, 400-408 receiving aspirin (3), the underlying mechanism for gastric mucosal damage remains unclear (1).

We and others have observed that salicylate and nonsalicylate nonsteroidal anti-inflammatory drugs (NSAIDs) stimulated basal acid secretion in vivo and potentiated histaminestimulated acid secretion in vivo and in vitro (4-8), suggesting that enhanced gastric acid secretion could play a role in the pathogenesis of NSAIDs-induced gastrointestinal mucosal injury.

Secretion of acid is regulated by specific agonists (i.e., histamine, acetylcholine, and gastrin) bound to cell membrane receptors via at least two intracellular second messengers, cyclic AMP (cAMP) and calcium $\left(\mathrm{Ca}^{2+}\right)$, the latter being regulated by inositol 1,4,5-triphosphate $\left(\mathrm{IP}_{3}\right)$ and 1,2-diacylglycerol (DAG) $(9,10)$. Prior data suggest that a rise in intracellular free $\mathrm{Ca}^{2+}\left(\left[\mathrm{Ca}^{2+}\right]_{\mathrm{i}}\right)^{1}$ could act as a second messenger in parietal cells (PC) accounting for secretagogue-stimulated acid secretion $(9$, 10). Negulescu and Machem (11) recently demonstrated separate stimulatory pathways for $\mathrm{Ca}^{2+}$ and cAMP in PC. While a cholinergic agonist, carbachol, only elevates $\left[\mathrm{Ca}^{2+}\right]_{\mathrm{i}}$ via muscarinic receptors (12), histamine increases both cAMP and $\left[\mathrm{Ca}^{2+}\right]_{i}$ via $\mathrm{H}_{2}$ receptors (11) leading to a secretory response. The results reported here implicate an intracellular $\mathrm{Ca}^{2+}$-dependent pathway as a mediator of aspirin-induced augmentation of secretagogue-stimulated acid secretion and this potentiation may be modulated by $\mathrm{PGE}_{2}$.

\section{Methods}

Isolation of glands and cells. Fundic glands (FG) and PC were isolated from New Zealand white rabbits (weighing $2.5-3.0 \mathrm{~kg}$ ) using the method of Berglindh and Obrink (13) and a modification of Berglindh's method (14), as we previously reported (15). Briefly, PC were separated by enzyme digestion and purified to $80-90 \%$ by Nycodenz density gradient centrifugation. The $\mathrm{PC}$ were washed three times with

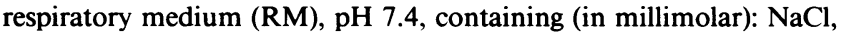
132, $\mathrm{KCl}, 5.4, \mathrm{NaH}_{2} \mathrm{PO}_{4}, 1.0, \mathrm{Na}_{2} \mathrm{HPO}_{4}, 5, \mathrm{MgSO}_{4}, 1.2, \mathrm{CaCl}_{2}, 1.0$, D-glucose, 11 , and bovine serum albumin, $2 \mathrm{mg} / \mathrm{ml}$. In some experiments PC were washed once with $\mathrm{Ca}^{2+}$-free $\mathrm{RM}$ containing $0.2 \mathrm{mM}$ EGTA, then once with $\mathrm{Ca}^{2+}$-free $\mathrm{RM}$ to remove extracellular $\mathrm{Ca}^{2+}$ $\left[\mathrm{Ca}^{2+}\right]_{0}$ and finally resuspended in $\mathrm{Ca}^{2+}$-free or $0.2 \mathrm{mM}$ EGTA containing RM. During lanthanum chloride $\left(\mathrm{La}^{3+}\right)$ experiments, a sulfateand phosphate-free $\mathrm{RM}, \mathrm{pH} 7.4$, containing $30 \mathrm{mM}$ Hepes was used. Viability of FG or PC preparations were determined by erythrosin B dye exclusion and only those having $>90 \%$ viability were used.

Aminopyrine (AP) uptake ratio. AP uptake determinations were performed as previously described (16). After a 10 -min preincubation,

1. Abbreviations used in this paper: AP, aminopyrine; ASA, aspirin; $\left[\mathrm{Ca}^{2+}\right]_{i}$, intracellular free calcium concentration; $\left[\mathrm{Ca}^{2+}\right]_{\mathrm{o}}$, extracellular calcium; DAG, 1,2,-diacylglycerol; dbcAMP, $N^{6}, 2^{\prime}$ - $O$-dibutyryl adenosine 3,5-cyclic monophosphate; dmPGE $2,16,16$-dimethyl $\mathrm{PGE}_{2}$; FG, fundic glands; fura-2/AM, fura-2 acetoxymethyl ester; IBMX, 3-isobutyl-1-methylxanthine; $\mathrm{IP}_{3}$, inositol 1,4,5-trophosphate; $\mathrm{La}^{+3}$, lanthanum chloride; PC, parietal cells; PKA, protein kinase A; PKC, protein kinase C; RM, respiratory medium; SA, salicylic acid. 
an aliquot of $\mathrm{FG}$ or $\mathrm{PC}$ was incubated with $\left[{ }^{14} \mathrm{C}\right]$ aminopyrine $(118$ $\mathrm{mCi} / \mathrm{mmol}$ ) at a concentration of $0.1 \mu \mathrm{Ci} / \mathrm{ml}$ for $10 \mathrm{~min}$ at $37^{\circ} \mathrm{C} .1-\mathrm{ml}$ aliquots of FG or PC were added to the various concentrations of test agents, incubated for $20 \mathrm{~min}$ at $37^{\circ} \mathrm{C}$ with shaking, the suspensions centrifuged, and supernatant removed. The pellet was solubilized and counted in a liquid scintillation counter (Beckman LS-355). The AP accumulation was determined as the ratio of intra- to extracellular AP.

Measurement of $\left[\mathrm{Ca}^{2+}\right]_{i}$. PC $\left(10^{6}\right.$ cells/ml $)$ were loaded with the fluorescent $\mathrm{Ca}^{2+}$ indicator fura-2/AM, using the method of Negulescu and Machem (11). In some experiments PC were washed three times with $\mathrm{Ca}^{2+}$-free $\mathrm{RM}$ containing $0.2 \mathrm{mM}$ EGTA to deplete both intraand extracellular $\mathrm{Ca}^{2+}$ and used for fluorescent measurement, according to Malinowska et al. (17). $\mathrm{Ca}^{2+}$ signals were obtained at $37^{\circ} \mathrm{C}$ using a modular fluorometer system (Fluorolog 2 , model CM3) coupled to a Spex Datamate microcomputer. Fluorescence was monitored at 340/380-nm excitation and 510-nm emission $(18,19)$. Data points were collected every $4 \mathrm{~s}$. Calibration was performed using $1 \%$ (vol/vol) Triton X-100 and $10 \mathrm{mM}$ EGTA for maximal and minimal fluorescence, respectively. Autofluorescence of each control sample was subtracted from their respective experimental values. $\left[\mathrm{Ca}^{2+}\right]_{\mathbf{i}}$ concentration was calculated as described previously $(18,19)$.

Addition of aspirin at any concentration to the $\mathrm{Ca}^{2+} /$ fura-2 buffer did not affect the $\mathrm{Ca}^{2+} /$ fura-2 fluorescence. However, in control PC buffer without fura-2, aspirin exhibited autofluorescence between aspirin concentrations of $2 \times 10^{-5}$ to $10^{-4} \mathrm{M}$. Autofluorescence of aspirin was subtracted from the experimental value of $\mathrm{Ca}^{2+} /$ fura-2 fluorescence and $\left[\mathrm{Ca}^{2+}\right]_{\mathrm{i}}$ calculated in experiments using $2 \times 10^{-5} \mathrm{M}$ aspirin, while at higher concentrations $\left(>2 \times 10^{-5} \mathrm{M}\right)$, all experimental values were deleted because of large autofluorescence which interfered with $\mathrm{Ca}^{2+} /$ fura-2 fluorescence.

Cyclic AMP (cAMP) assay. cAMP was measured according to the method of Schwartzel et al. (20). Briefly, PC $\left(5 \times 10^{6} \mathrm{cells} / \mathrm{ml}\right)$ were incubated with different agents for $20 \mathrm{~min}$. The total cAMP content of PC plus medium was extracted with $5 \%$ (vol/vol) trichloroacetic acid and freeze/thawing. cAMP was measured using a radioimmunoassay method (Amersham Corp., Arlington Heights, IL). Values were expressed as pmol cAMP $/ 10^{6}$ cells.

Measurement of inositol phosphates. PC $\left(10^{8}\right.$ cells) were prelabeled for $2 \mathrm{~h}$ at $37^{\circ} \mathrm{C}$ in $10 \mathrm{ml}$ of $30 \mathrm{mM}$ Hepes buffer, (pH 7.4), containing (in millimolar): $\mathrm{NaCl}, 132, \mathrm{KCl}, 5.4, \mathrm{CaCl}_{2}, 1.2, \mathrm{NaHCO}_{3}, 3.6, \mathrm{MgCl}_{2}$, 1.0 and D-glucose, 5.5 , in the presence of $50-100 \mu \mathrm{Ci}$ of $\left[{ }^{3} \mathrm{H}\right]$ myoinositol and equilibrated with $95 \% \mathrm{O}_{2}-5 \% \mathrm{CO}_{2}(21)$. During the last 10 min of incubation, lithium chloride was added to a final concentration of $20 \mathrm{mM}$. Aliquots of prelabeled PC were further incubated for 5 and $30 \mathrm{~min}$ in the presence and absence of test substances. Incubations were terminated by the addition of $1.5 \mathrm{ml}$ chloroform/methanol (1:2). The total water-soluble inositol phosphates were separated from $\left[{ }^{3} \mathrm{H}\right]$ inositol by ion exchange chromatography and quantified using the method of Berridge et al. (22).

$\mathrm{H}^{+}, \mathrm{K}^{+}$-ATPase activity of gastric microsomes. Rabbit gastric microsomes were prepared and assayed for $\mathrm{H}^{+}, \mathrm{K}^{+}$-ATPase activity as described previously (23), in the presence and absence of two concentrations of aspirin.

Prostaglandin analysis. $\mathrm{PGE}_{2}$ was measured by the method of Wallace and Cohen (24), as described previously (16). Briefly, isolated PC, $5 \times 10^{6}$ cells $/ \mathrm{ml}$ respiratory medium, were incubated for different times at $37^{\circ} \mathrm{C}$ in the presence of various agents. The suspension was then centrifuged and the pellet resuspended in $3 \mathrm{ml}$ water. This suspension was freeze/thawed three times followed by the addition of $\left[{ }^{3} \mathrm{H}\right] \mathrm{PGE}_{2}(\sim 4,000 \mathrm{cpm})$ and $30 \mu \mathrm{l}$ of $1 \mathrm{M}$ citrate to each sample. This mixture was vortexed and extracted three times with ethyl acetate. Final purification was performed by silicic acid column chromatography using benzene, ethyl acetate, and methanol solvent systems. $\mathrm{PGE}_{2}$ was determined by radioimmunoassay (Seragen Inc., Boston, MA)

Materials. All chemicals were the highest grade available; collagenase, protease, dimethyl prostaglandin $\mathrm{E}_{2}\left(\mathrm{dmPGE}_{2}\right)$, prostaglandin $\mathrm{E}_{2}\left(\mathrm{PGE}_{2}\right)$, inositol 1,4,5-triphosphate, histamine-dihydrochloride, 3isobutyl-1-methylxanthine (IBMX), carbachol, Na-salicylate, and aspirin were obtained from Sigma Chemical Co. (St. Louis, MO); pronase and Nycodenz were obtained from E. Merck (Darmstadt, West Germany) and Accurate Chemical \& Scientific Co. (Westbury, NY), respectively. $\left[{ }^{14} \mathrm{C}\right]$ Aminopyrine, $\left[{ }^{14} \mathrm{C}\right]$ glucose, ${ }^{45} \mathrm{Ca}^{2+}$, and $\left[{ }^{3} \mathrm{H}\right]$ $\mathrm{IP}_{3}$ were obtained from New England Nuclear (Boston, MA). $\left[{ }^{3} \mathrm{H}\right] \mathrm{CAMP}$ and $\left[{ }^{3} \mathrm{H}\right]$ myoinositol were obtained from Amersham. $\left[{ }^{3} \mathrm{H}\right] \mathrm{PGE}_{2}$ was obtained from Seragan, Inc. Forskolin and fura-2/AM were obtained from Calbiochem Co. (La Jolla, CA). Dibutyryl cyclic AMP (dbcAMP) was obtained from Boehringer-Mannheim (Mannheim, West Germany). Cimetidine was purchased from SmithKline Laboratories (Philadelphia, PA).

Aspirin and salicylic acid were dissolved in $50-100 \mu \mathrm{l}$ of $10 \mathrm{mM}$ $\mathrm{NaOH}$ and adjusted to $\mathrm{pH} 7.5$ by $1 \mathrm{mM} \mathrm{HCl}$ after dilution in water. Fura-2/AM, IBMX, dmPGE ${ }_{2}$ and forskolin were dissolved in dimethyl sulfoxide in such a way that the final experimental concentration was not more than $1 \%$.

Statistical evaluation. The $n$ in all data equals the number of animals used. Data expressed as mean \pm SEM. To determine statistical significance, we used either the Student $t$ test for paired experimental studies or ANOVA, followed by the Student Newman-Keuls test for multiple comparisons with the same control. Significance was accepted at $P<0.05$.

\section{Results}

Effects of aspirin on AP uptake ratio. Aspirin $\left(10^{-6}-10^{-4} \mathrm{M}\right)$ potentiated maximal histamine-stimulated $\left[{ }^{14} \mathrm{C}\right] \mathrm{AP}$ uptake ratio in $\mathrm{PC}$ by 70,97 , and $54 \%$, respectively (Fig. 1). Under the same conditions of 5-min incubation, aspirin $\left(10^{-6}-10^{-4} \mathrm{M}\right)$ failed to potentiate AP uptake in FG, (Fig. 1). However, FG which were incubated for a prolonged time (30-45 $\mathrm{min})$ with aspirin $\left(10^{-5} \mathrm{M}\right)$ also potentiated histamine-stimulated AP uptake (Fig. 1), implying a greater permeability barrier to aspirin in FG compared to PC. In contrast to aspirin, salicyclic acid $\left(10^{-6}-10^{-4} \mathrm{M}\right)$ after either $5 \mathrm{~min}$ incubation with PC or 5 and 30-45 min incubation with FG, failed to augment histamine-stimulated AP uptake (Fig. 1).

Fig. 2 shows the effect of aspirin $\left(10^{-5} \mathrm{M}\right)$ on various secretagogue-stimulated AP uptake ratios. Like histamine, other secretagogues, including 3-isobutyl-1-methylxanthine (IBMX, $\left.10^{-4} \mathrm{M}\right)$, a phosphodiesterase inhibitor, forskolin $\left(10^{-5} \mathrm{M}\right)$, a diterpine that activates the catalytic subunit of adenylate cyclase and dbcAMP $\left(10^{-3} \mathrm{M}\right)$ stimulated AP uptake and were potentiated by aspirin $32 \%, 34 \%$, and $56 \%$, respectively, compared to their controls. Compared to histamine-stimulated AP uptake $(100 \%)$, carbachol $\left(10^{-4} \mathrm{M}\right)$-stimulated AP uptake was much lower (23\%). Aspirin did not potentiate carbachol-stimulated AP uptake in contrast to its enhancement of other secretagogues (Fig. 2).

Fig. 3 demonstrates that histamine-stimulated AP uptake and its potentiation by aspirin was blocked by the $\mathrm{H}_{2}$ receptor antagonist, cimetidine $\left(2 \times 10^{-4} \mathrm{M}\right)$. In contrast, cimetidine was unable to block dbcAMP-stimulated AP uptake and its potentiation by aspirin, indicating that cimetidine inhibited histamine stimulation per se rather than the potentiating effect of aspirin. Fig. 3 also shows that a $\mathrm{Ca}^{2+}$-free medium or the addition of $\mathrm{La}^{3+}\left(2.5 \times 10^{-4} \mathrm{M}\right)$ did not significantly alter histamine- or dbcAMP-stimulated AP uptakes, the responses being maintained at $80-90 \%$ of their $\mathrm{Ca}^{2+}$-supplemented controls. On the other hand, enhancement of maximal histamineor dbcAMP-stimulated AP uptakes by aspirin was prevented during incubation in a $\mathrm{Ca}^{2+}$-free medium or by pretreatment with $\mathrm{La}^{3+}$, indicating that these responses were dependent on $\left[\mathrm{Ca}^{2+}\right]_{0}$. 


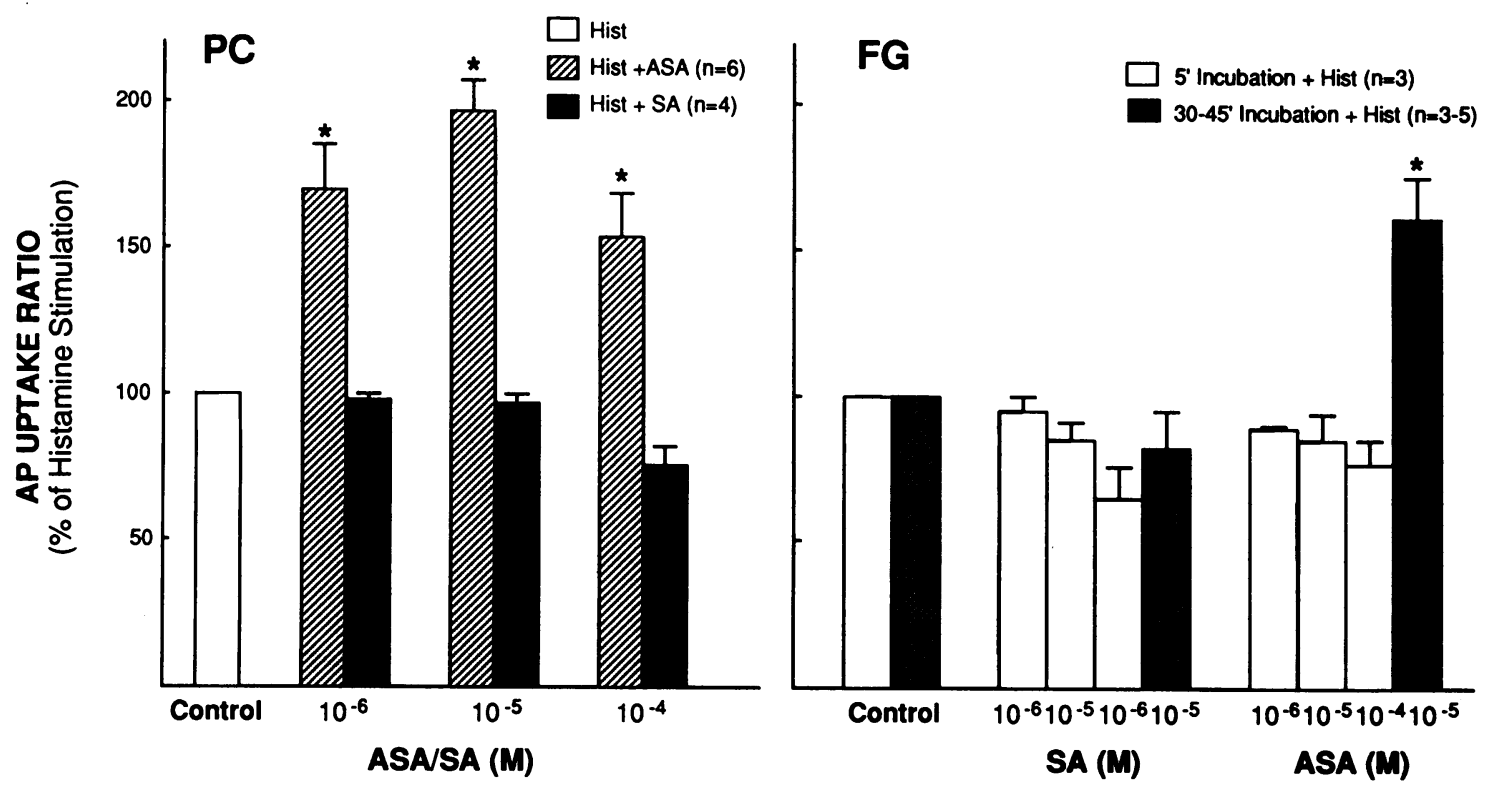

Figure 1. AP uptake ratio responses to different concentrations of aspirin (ASA) and salicyclic acid (SA) in PC (left panel) and FG (right panel). The values on the ordinate are expressed as the percentage of AP uptake ratio measured at 20 min in histamine-stimulated minus basal (RM alone) AP uptake ratios. Basal and histamine-stimulated uptake ratios were, respectively, for PC $21 \pm 2$ and $49 \pm 3$ and for FG $21 \pm 2$ and $49 \pm 4$ (5 min incubation) and $20 \pm 1$ and $45 \pm 3$ (30-45 min incubation). ${ }^{*} P<0.05$ compared with response to histamine alone (control).

Fig. 4 shows the effects of aspirin on basal and histaminestimulated AP uptake either in the presence or absence of $\mathrm{La}^{3+}$. Aspirin increased AP uptake by $63 \%$ above histamine stimulation within 30 min without affecting basal AP uptake. Histamine-stimulated AP uptake was reduced by $20 \%$ with respect to its control level after 30 min treatment with $\mathrm{La}^{3+}$ (Fig. 4). When $\mathrm{La}^{3+}$ was added in conjunction with aspirin after 30 min stimulation of PC by histamine, a significant reversal of the aspirin-induced potentiation of stimulated AP uptake occurred at 15 min and continued for the next 15 min to the level of histamine with $\mathrm{La}^{3+}$. These results indicate that intracellular $\mathrm{Ca}^{2+}$ is important for the initial potentiation of

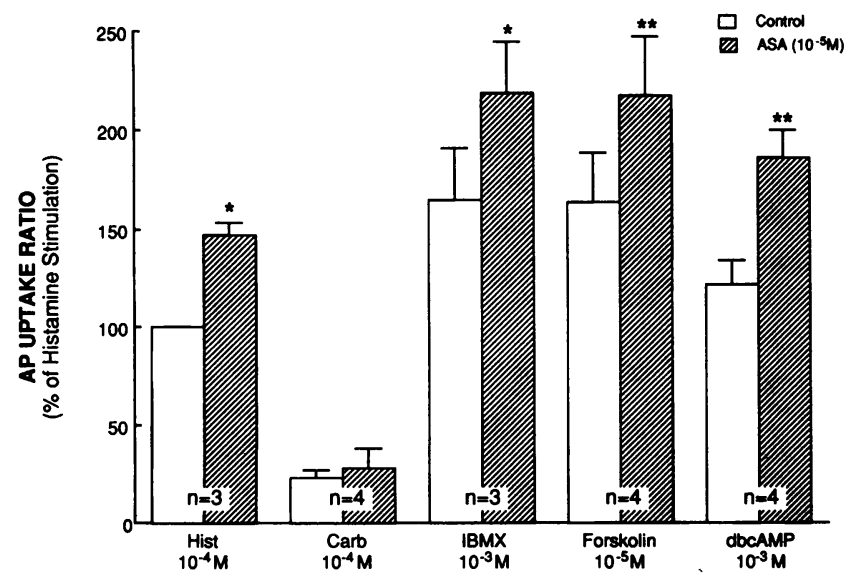

Figure 2. Effect of ASA on secretagogue-stimulated AP uptake ratios in PC. Values are expressed as percentage of AP uptake ratio measured at $20 \mathrm{~min}$ in histamine-stimulated PC. Basal and histamine(Hist)-stimulated AP uptake ratios were, respectively, $30 \pm 4$ and $234 \pm 33$. ${ }^{*} P<0.02,{ }^{* *} P<0.01$ compared with respective secretagogue alone (control versus aspirin).
AP uptake by aspirin and subsequent maintenance of potentiation is dependent on $\left[\mathrm{Ca}^{2+}\right]_{0}$.

Effect of aspirin on $\left[\mathrm{Ca}^{2+}\right]_{i}$. Representative $\left[\mathrm{Ca}^{2+}\right]_{\mathrm{i}}$ responses to carbachol, histamine and aspirin are shown in Fig. 5 $A$. The $\left[\mathrm{Ca}^{2+}\right]_{\mathrm{i}}$ responses to carbachol and histamine were abolished by prior addition of atropine $\left(10^{-4} \mathrm{M}\right)$ or cimetidine $(2$ $\times 10^{-4} \mathrm{M}$ ), respectively (Fig. $5 \mathrm{~B}$ ). The aspirin-induced $\left[\mathrm{Ca}^{2+}\right]_{\mathrm{i}}$ response was unaffected by either atropine and/or cimetidine

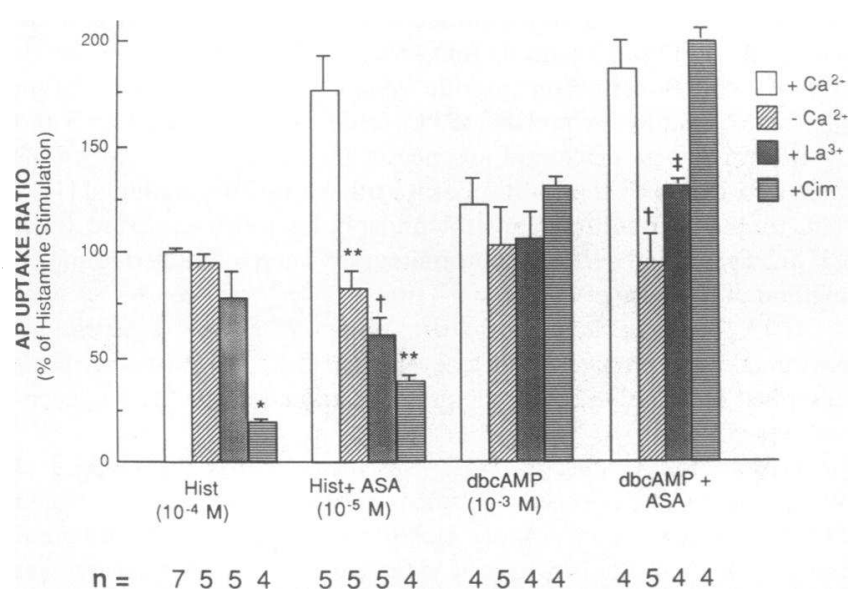

Figure 3. Effect of aspirin (ASA)-pretreatment ( $5 \mathrm{~min}$ ) on histamine (Hist) $\left(10^{-4} \mathrm{M}\right)$ - or dbcAMP $\left(10^{-3} \mathrm{M}\right)$-stimulated AP uptake ratios in $\mathrm{PC}$ under various conditions (presence or absence of $\mathrm{Ca}^{2+}, \mathrm{La}^{3+}$ and cimetidine [Cim]) for $20 \mathrm{~min}$ at $37^{\circ} \mathrm{C} . \mathrm{La}^{3+}\left(2.5 \times 10^{-4} \mathrm{M}\right)$ and cimetidine $\left(2 \times 10^{-4} \mathrm{M}\right)$ were added $5 \mathrm{~min}$ before administration of secretagogues. Values expressed as percentage of AP uptake ratio measured at 20 min in histamine-stimulated PC. Basal, histamine and dbcAMP-stimulated AP uptake ratios were, respectively, 23 \pm 2 , $75 \pm 2$ and $91 \pm 6$. $P$ values represented as $<0.001^{*} ;<0.01^{* *}$; $<0.02^{+}$and $<0.05$.+ $^{++}$ 


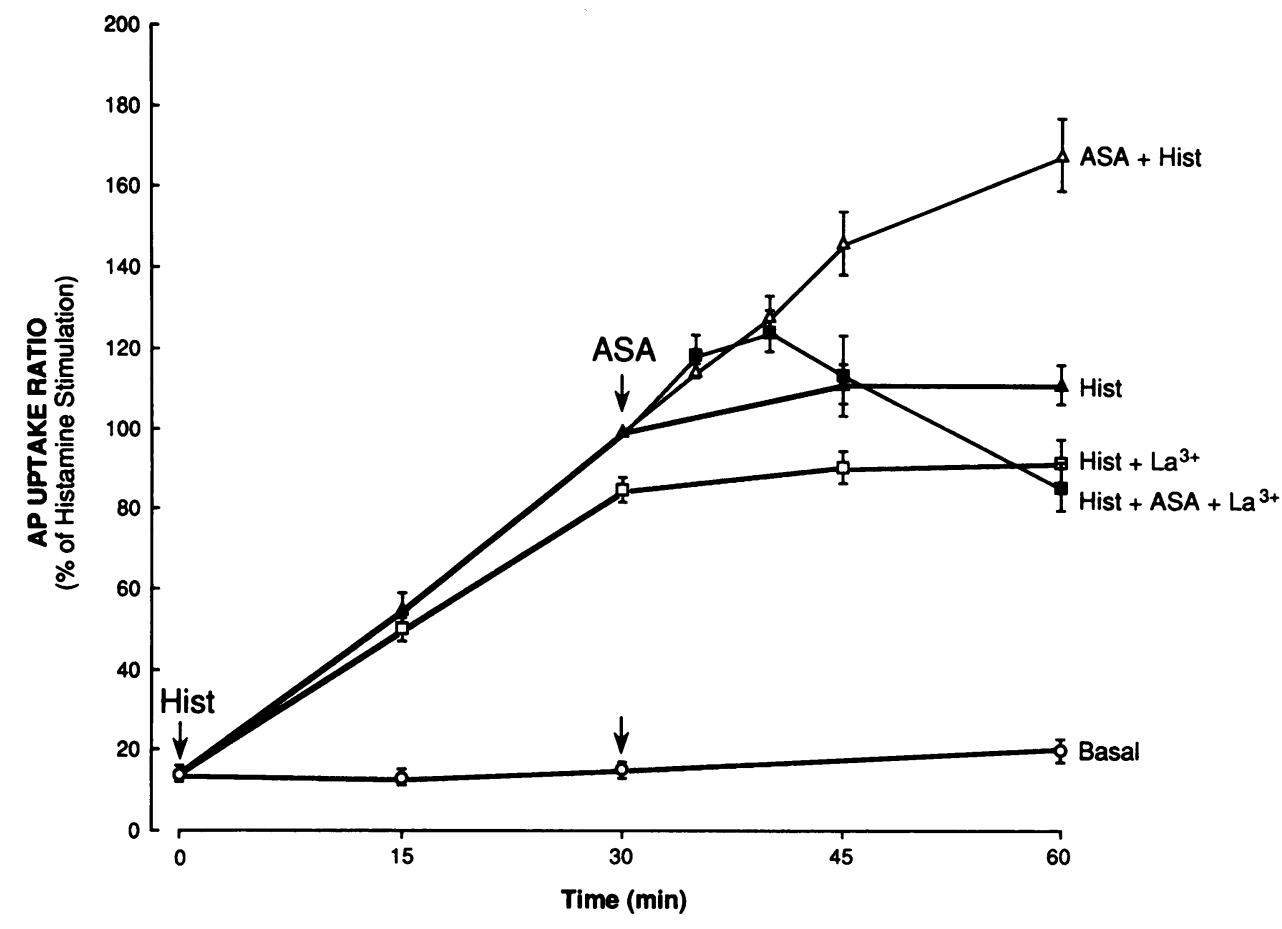

Figure 4. Time course of aspirin potentiation of histamine-stimulated AP uptake ratio in PC. Histamine $\left(10^{-4} \mathrm{M}\right)$ was added initially at zero time in the presence ( $\square$ ) and absence $(\Lambda)$ of $\mathrm{La}^{3+}\left(2.5 \times 10^{-4} \mathrm{M}\right)$, except under basal conditions ( 0 ). Aspirin $\left(10^{-5} \mathrm{M}\right)$ addition after 30 min of histamine exposure in conjunction with $(\square)$ or without $(\Delta)$ $\mathrm{La}^{3+}$. Values are expressed as percentage of AP uptake ratio measured at $30 \mathrm{~min}$ in histamine-stimulated PC from 5 to 10 separate experiments. Basal AP uptake ratio was $33 \pm 3$. Histamine-stimulated AP uptake ratio at $30 \mathrm{~min}$, i.e., $100 \%$, was $294 \pm 25$. Arrows indicate addition of histamine (Hist) or aspirin (ASA).
(Fig. $5 \mathrm{~B}$ ) suggesting its independence from interaction with muscarinic or $\mathrm{H}_{2}$ receptors. Using prolonged EGTA-washed PC (three 15-min consecutive washes) to deplete $\mathrm{Ca}^{2+}$ from intra- and extracellular sites (17, Fig. $5 C$ ), neither carbachol, histamine, or aspirin significantly increased $\left[\mathrm{Ca}^{2+}\right]_{\mathrm{i}}$. The prolonged EGTA-washed PC experiments suggest that intracellu- lar $\mathrm{Ca}^{2+}$ stores were depleted, since both aspirin- and secretagogue-dependent increases in $\left[\mathrm{Ca}^{2+}\right]_{i}$ were abolished. Subsequent addition of $1 \mathrm{mM} \mathrm{Ca}^{2+}$ to the medium increased $\left[\mathrm{Ca}^{2+}\right]_{\mathrm{i}}$ to levels of controls supplemented with $\mathrm{Ca}^{2+}$, indicating that PC remained responsive (Fig. $5 C$ ). Fig. $5 \mathrm{D}$ demonstrates that after a single EGTA wash of $\mathrm{PC}$, which depletes only $\left[\mathrm{Ca}^{2+}\right]_{0}$,

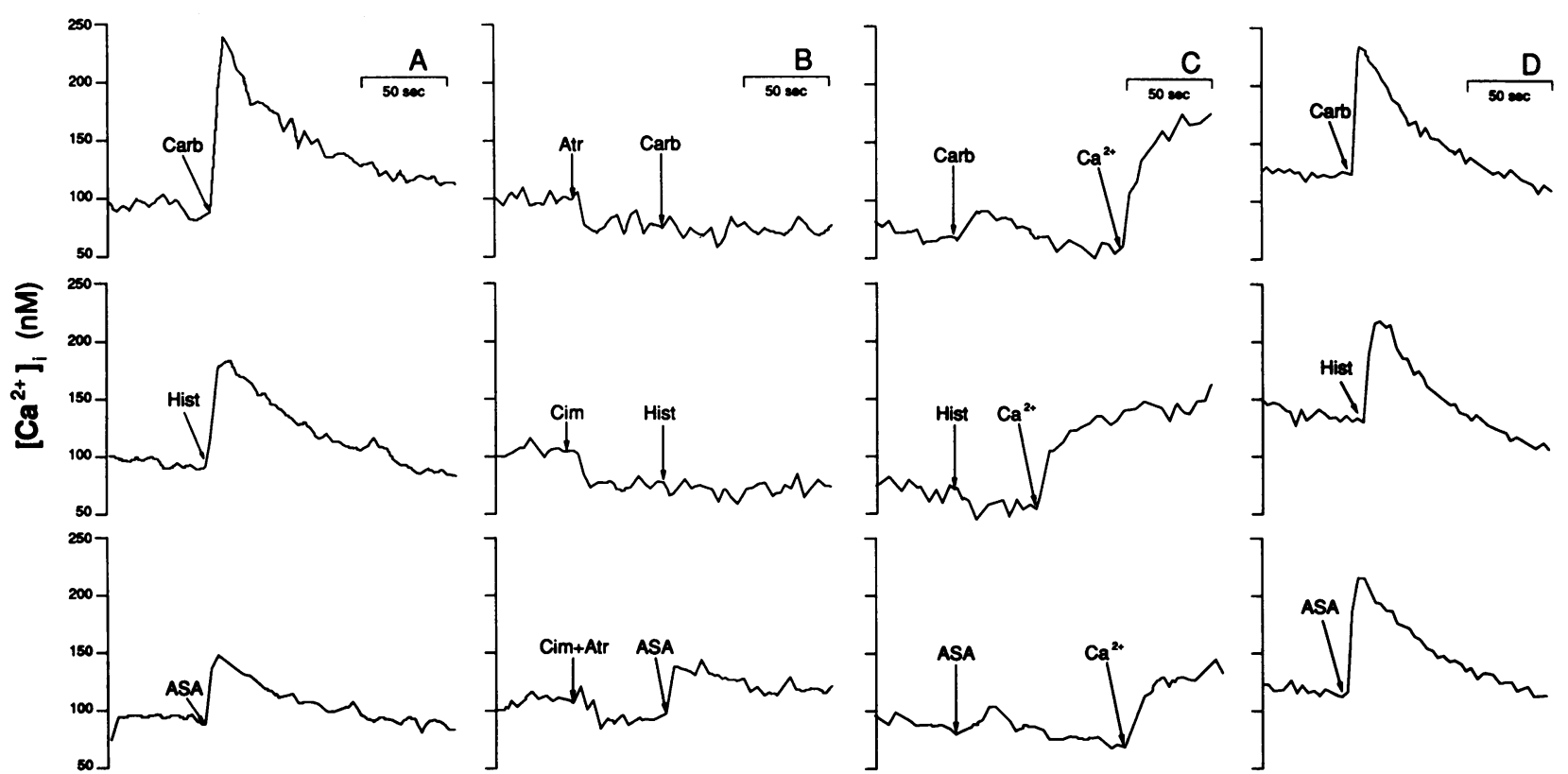

Figure 5. Representative $\left[\mathrm{Ca}^{2+}\right]_{\mathrm{i}}$ responses to aspirin, carbachol and histamine in $\mathrm{PC}$ under various conditions. $(A) \mathrm{PC}\left(10^{6}\right.$ cells/ml) were loaded with fura-2/AM in medium containing $1 \mathrm{mM} \mathrm{Ca}{ }^{2+}$, as described in the text (Methods). $\left[\mathrm{Ca}^{2+}\right]_{i}$ changes were measured in response to carbachol $\left(\mathrm{Carb}, 10^{-4} \mathrm{M}\right.$ ), histamine (Hist, $10^{-4} \mathrm{M}$ ) and aspirin (ASA, $10^{-5} \mathrm{M}$ ). (B) Effects of atropine (Atr, $10^{-4} \mathrm{M}$ ) and cimetidine (Cim, 2 $\left.\times 10^{-4} \mathrm{M}\right)$ on carbachol, histamine and aspirin-induced $\left[\mathrm{Ca}^{2+}\right]_{\mathrm{i}}$ responses. $(C) \mathrm{Ca}^{2+}$-depleted PC were loaded with fura-2/AM in $\mathrm{Ca}^{2+}-$ free medium containing $0.2 \mathrm{mM}$ EGTA and $\left[\mathrm{Ca}^{2+}\right]_{i}$ changes were monitored. $(D)\left[\mathrm{Ca}^{2+}\right]_{\mathrm{i}}$ responses to carbachol, histamine and aspirin in $\mathrm{Ca}^{2+}-\mathrm{de}-$ pleted PC after a single EGTA wash of PC in presence of $0.2 \mathrm{mM}$ EGTA: Data are a representative example of individual experiments repeated 4-12 times. Arrows indicate the point where agents were added. 
Table I. $\left[\mathrm{Ca}^{2+}\right]_{i}$ Increment, cAMP Content, and IP ${ }_{3}$ Levels in PC after Treatment with Aspirin (ASA),

Salicylic acid $(S A)$, and Secretagogues

\begin{tabular}{|c|c|c|c|c|}
\hline \multirow[t]{2}{*}{ Agents } & \multirow{2}{*}{$\frac{\Delta\left[\mathrm{Ca}^{2+}\right]_{\mathrm{i}}(\mathrm{nM})}{4-8 s}$} & \multirow{2}{*}{$\frac{\text { cAMP }\left(\mathrm{pmol} / 10^{6} \text { cells }\right)}{20 \mathrm{~min}}$} & \multicolumn{2}{|c|}{$\mathrm{IP}_{3}\left(\mathrm{cpm} / 4 \times 10^{6}\right.$ cells, $\left.n=5\right)$} \\
\hline & & & $5 \mathrm{~min}$ & $30 \mathrm{~min}$ \\
\hline Control (basal) & 0 & $2.1 \pm 0.1(4)$ & $103 \pm 11$ & $116 \pm 17$ \\
\hline Carbachol $\left(10^{-4} \mathrm{M}\right)$ & $110 \pm 11(23)$ & $2.2(1)$ & $163 \pm 27^{* *}$ & $116 \pm 19$ \\
\hline $\mathrm{SA}\left(10^{-5} \mathrm{M}\right)$ & $0(2)$ & $2.0(1)$ & ND & ND \\
\hline $\operatorname{ASA}\left(10^{-5} \mathrm{M}\right)$ & $45 \pm 4(24)$ & $2.2 \pm 0.2(4)$ & $104 \pm 23$ & $77 \pm 6$ \\
\hline Histamine $\left(10^{-4} \mathrm{M}\right)$ & $64 \pm 15(9)$ & $5.5 \pm 0.5^{*}(4)$ & $122 \pm 20$ & $125 \pm 48$ \\
\hline Histamine $\left(10^{-4} \mathrm{M}\right)+\operatorname{ASA}\left(10^{-5} \mathrm{M}\right)$ & $68 \pm 10(6)$ & $5.3 \pm 0.5 *(4)$ & $135 \pm 41$ & $128 \pm 52$ \\
\hline $\operatorname{IBMX}\left(10^{-4} \mathrm{M}\right)$ & $83 \pm 23(2)$ & $31.1 \pm 1.6^{*}(2)$ & ND & ND \\
\hline Forskolin $\left(10^{-5} \mathrm{M}\right)$ & $55 \pm 17(8)$ & $118.3 \pm 7.5^{*}(2)$ & ND & ND \\
\hline $\operatorname{dbcAMP}\left(10^{-3} \mathrm{M}\right)$ & $0(2)$ & ND & ND & ND \\
\hline
\end{tabular}

Number of experiments shown in parentheses. Values are mean \pm SEM. ${ }^{*} P<0.01,{ }^{* *} P<0.05$ compared with control value. ND, experiment not performed. $\Delta\left[\mathrm{Ca}^{2+}\right]_{i}$ calculated as peak stimulation minus basal values. Basal mean $\left[\mathrm{Ca}^{2+}\right]_{\mathrm{i}}$ levels $=119 \pm 6 \mathrm{nM},(n=76)$. cAMP and IP ${ }_{3}$ experiments performed, respectively, in triplicate and duplicate.

both secretagogues and aspirin increased $\left[\mathrm{Ca}^{2+}\right]_{\mathrm{i}}$ in a manner similar to controls supplemented with $\left[\mathrm{Ca}^{2+}\right]_{\mathrm{o}}$ (Fig. $5 \mathrm{~A}$ ). The incremental \% change in $\left[\mathrm{Ca}^{2+}\right]_{i}$, in the presence and absence (single EGTA wash) of $\mathrm{Ca}^{2+}$ was, respectively, for carbachol, $78 \pm 14$ and $71 \pm 9$, for histamine $53 \pm 15$ and $53 \pm 15$ and for aspirin $58 \pm 12$ and $64 \pm 13(n=4)$.

The delta increment between resting and peak stimulated $\left[\mathrm{Ca}^{2+}\right]_{\mathrm{i}}$ levels induced within 4-8 s by different secretagogues, aspirin, and salicylate is shown in Table I. Aspirin in conjunction with histamine was not additive to the increase in $\left[\mathrm{Ca}^{2+}\right]_{i}$ by histamine alone. Salicylic acid and dbcAMP did not change $\left[\mathrm{Ca}^{2+}\right]_{\mathrm{i}}$ (Table I).

Aspirin-induced augmentation of $\left[\mathrm{Ca}^{2+}\right]_{i}$ was dose dependent, as shown in Fig. 6. Lineweaver-Burk plot of the data shows that the half maximum effect of aspirin occurred at a concentration of $2.5 \times 10^{-6} \mathrm{M}$.
Effect of aspirin on cAMP synthesis. Histamine, IBMX and forskolin significantly increased cAMP content in PC within $20 \mathrm{~min}$ from a resting level of $2.1 \pm 0.1 \mathrm{pmol} / 10^{6} \mathrm{PC}$ (Table I). Carbachol, salicylate and aspirin did not alter resting cAMP levels and histamine-stimulated cAMP levels were also unaffected by aspirin (Table I). It appears therefore that the potentiation of secretagogue-induced acid secretion by aspirin is not dependent on cAMP generation.

Effect of aspirin on inositol phosphates synthesis. Inositol $1,4,5$ triphosphate $\left(\mathrm{IP}_{3}\right)$ synthesis in $\mathrm{PC}$ is shown in Table I after 5 and 30 min treatment with different secretagogues and aspirin. Carbachol, as previously observed (21) increased at 5 min 1 monophosphate $(26 \pm 3 \%, P<0.01)$, inositol 1,4 biphosphate $(26 \pm 4 \%, P<0.01)$ and $\mathrm{IP}_{3}(54 \pm 11 \%, P<0.05$, Table I) with respect to their controls. Aspirin, histamine and aspirin with histamine- failed to alter phosphoinositide turn-

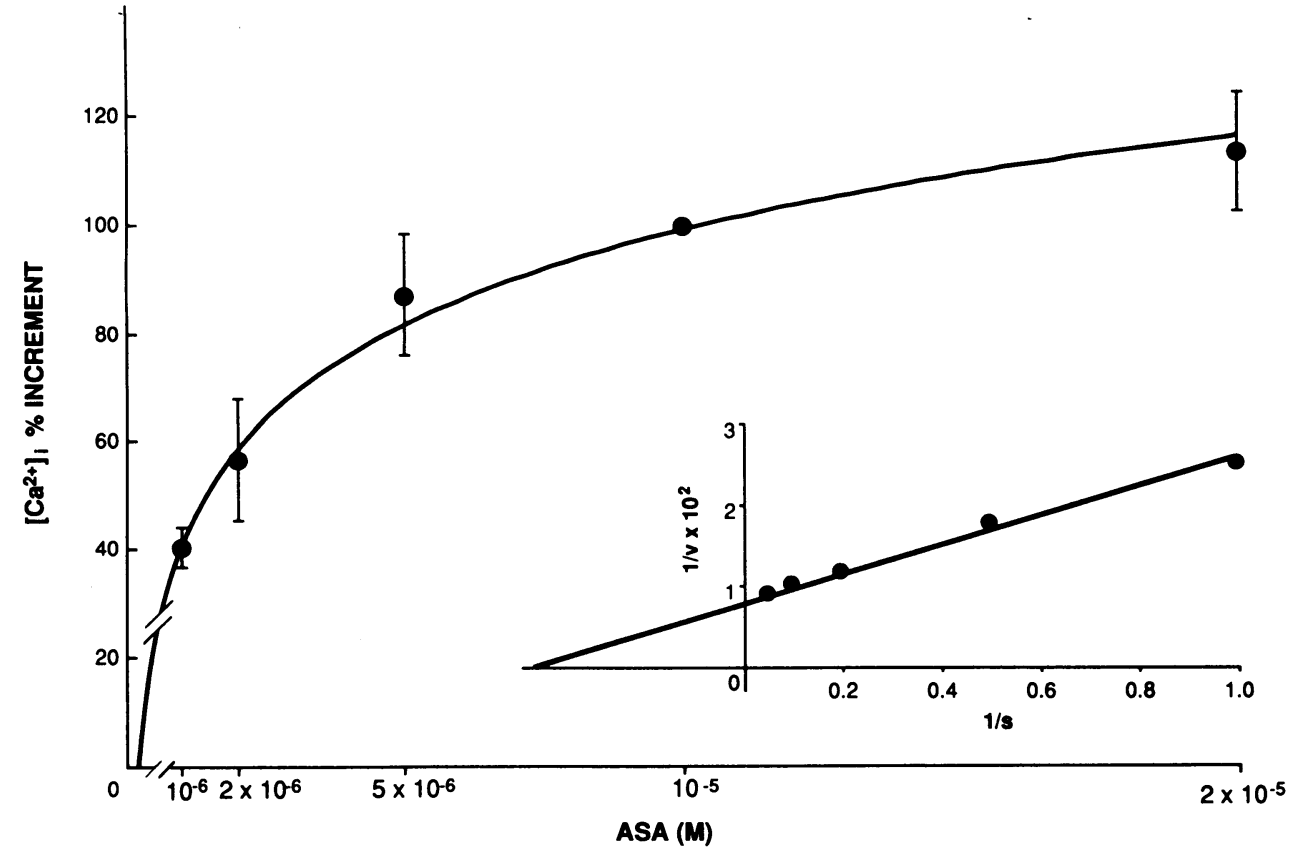

Figure 6. Effect of different concentrations of aspirin (ASA) on $\left[\mathrm{Ca}^{2+}\right]$ responses in PC. $\left[\mathrm{Ca}^{2+}\right]_{i}$ increment induced by aspirin on ordinate and concentration of $10^{-5} \mathrm{M}$ considered as $100 \%$. (Inset) Demonstrates Lineweaver-Burk plot of the data. Calculated $k_{\mathrm{m}}=2.5 \times 10^{-6}$ M. $n=3,6$, 10,16 , and 16 at, respectively, aspirin concentrations of $10^{-6}, 2$ $\times 10^{-6}, 5 \times 10^{-6}, 10^{-5}$, and 2 $\times 10^{-5} \mathrm{M}$. 


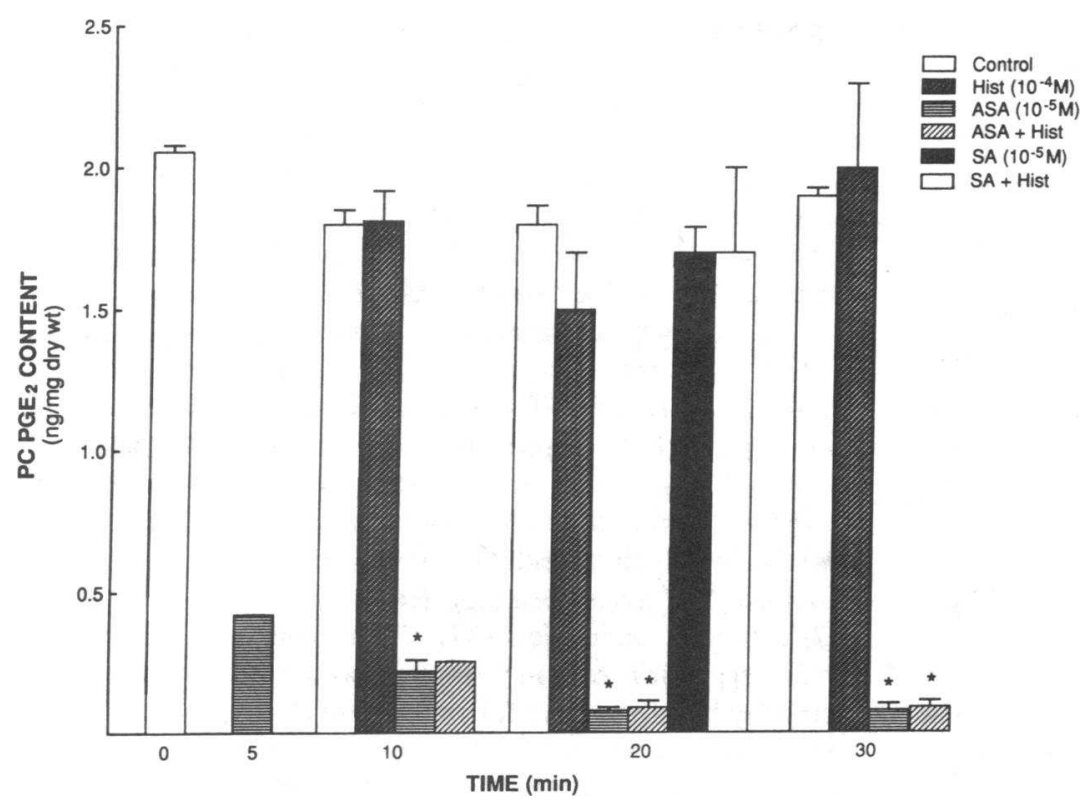

Figure 7. Effect of aspirin on $\mathrm{PGE}_{2}$ content in PC. ASA and SA are shown at varying times in the presence and absence of Hist. Data from three separate preparations performed in duplicate except for single experiment for ASA and for ASA + Hist at 5 and 10 min, respectively. ${ }^{*} P<0.05$ compared with their respective controls. over (data not shown) including $\mathrm{IP}_{3}$ (Table I). In a preliminary study we examined whether a more rapid and transient increase in $\mathrm{IP}_{3}$ could be produced by aspirin, employing a protein binding method for $\mathrm{IP}_{3}$ measurement, as described by Bredt et al. (25). Aspirin failed to alter $\mathrm{IP}_{3}$ levels within 10 to $120 \mathrm{~s}$ while carbachol increased $\mathrm{IP}_{3}$ by two- to threefold, as summarized: Control, aspirin and carbachol, respectively (in pmol $/ 10^{6}$ cells), 15,12 and $25(10 \mathrm{~s}) ; 13.5,11.1$ and 24.0 (20 s); $13,13.4$ and $42.0(60 \mathrm{~s})$; and $17.2,10.5$ and 45.0 (120 s).

Effect of aspirin on $\mathrm{H}^{+}, \mathrm{K}^{+}$-ATPase. Aspirin in concentrations between $10^{-5}-10^{-4} \mathrm{M}$ did not change $\mathrm{PC} \mathrm{H}^{+}, \mathrm{K}^{+}$-ATPase activity, as summarized: Control and aspirin $\left(10^{-5}\right.$ and $10^{-4}$ M) for crude microsome and purified membrane preparations, respectively ( $\mu \mathrm{mol} / \mathrm{mg}$ per $\mathrm{h}, n=4), 32 \pm 3,30 \pm 1$ and $32 \pm 7$; $55 \pm 3,52 \pm 4$ and 48 (single membrane preparation).

Effects of aspirin and salicylic acid on $P C P G E_{2}$ content. Aspirin reduced PC $\mathrm{PGE}_{2}$ content by $98 \%$ after 5-30 min treatment, in the presence and absence of histamine (Fig. 7). Both histamine and salicylic acid failed to alter significantly $\mathrm{PGE}_{2}$ levels.

Effect of dmPGE $E_{2}$ on AP uptake. Fig. 8 shows that exogenous $\mathrm{dmPGE} \mathrm{mPG}_{2}\left(10^{-7}-10^{-5} \mathrm{M}\right)$ inhibited histamine-stimulated AP uptake ( $\sim 30 \%$ of its control) and its potentiation by aspirin to the same extent. On the other hand, dbcAMP-stimulated AP uptake and its potentiation by aspirin were unaffected by $\mathrm{dmPGE}_{2}$ at a concentration of $10^{-7}-10^{-6} \mathrm{M}$

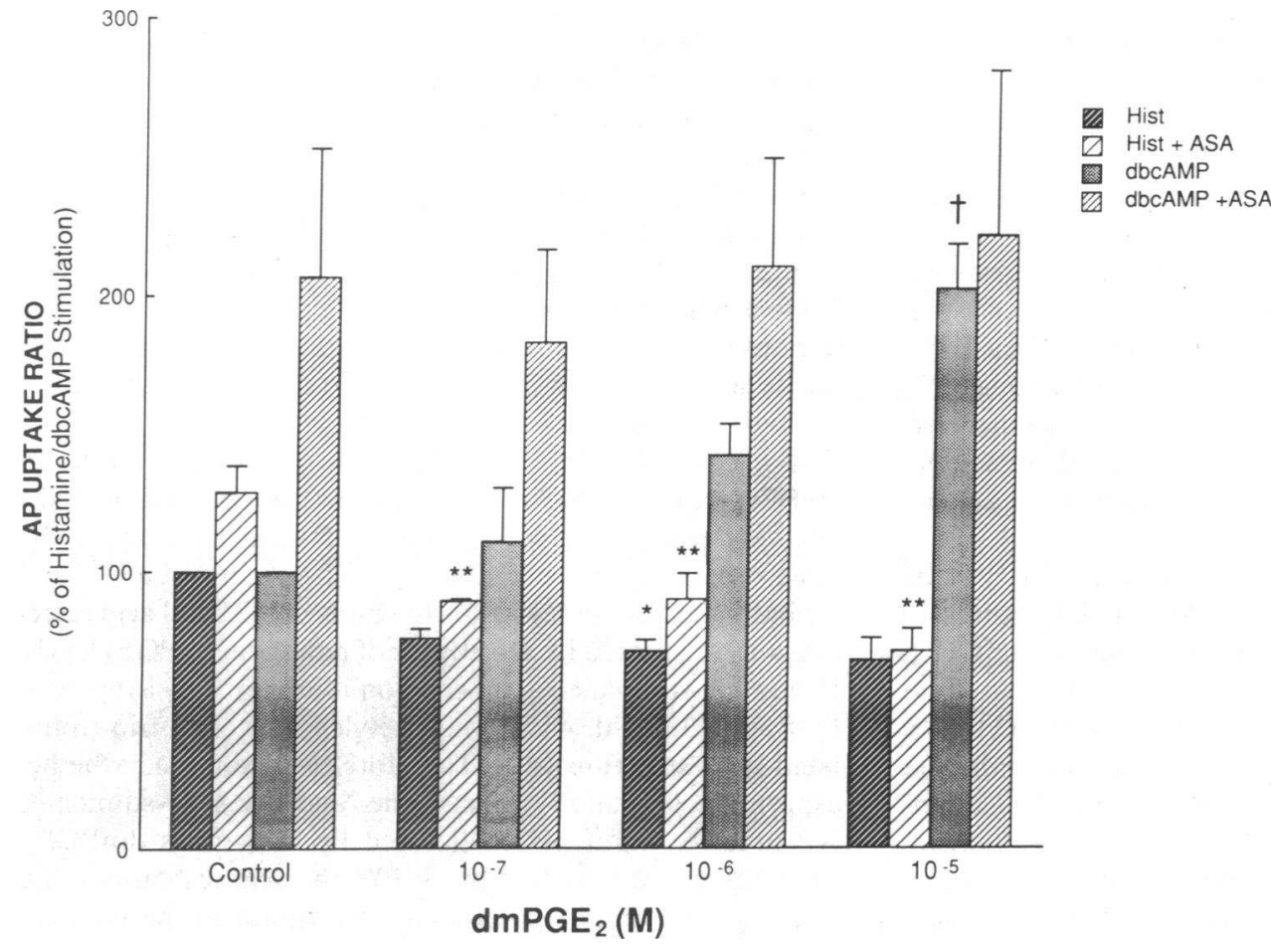

Figure 8. Effect of dmPGE 2 on histamine (Hist, $10^{-4} \mathrm{M}$ )- and dbcAMP $\left(10^{-3} \mathrm{M}\right)$-stimulated AP uptake ratio in $\mathrm{PC}$ in the presence and absence of aspirin (ASA, $10^{-5}$ M). Values expressed as $100 \%$ were $517 \pm 166(n=4)$ and $53 \pm 9(n$ $=3$ ), respectively, for histamineand dbcAMP-stimulated AP uptake ratios and basal values were, respectively $34 \pm 5$ and $22 \pm 4 .{ }^{*} P<0.05$ Hist versus Hist $+\mathrm{dmPGE}_{2} ;{ }^{* *} P$ $<0.05$ Hist + ASA vs. Hist + ASA + dmPGE $_{2} ;{ }^{+} P<0.05$ dbcAMP vs. $\mathrm{dbcAMP}+\mathrm{dmPGE}{ }_{2}$. 
$\mathrm{dmPGE}_{2}$ (Fig. 8). However, at a higher concentration $\left(10^{-5}\right.$ M), dmPGE ${ }_{2}$ increased significantly dbcAMP-stimulated AP uptake to a level not different from dbcAMP and aspirin-induced AP uptake, indicating that dmPGE $\mathrm{PB}_{2}$ blocked aspirin-induced potentiation of the dbcAMP-stimulated AP response.

\section{Discussion}

We have shown that aspirin potentiates secretagogue-stimulated acid secretion in PC, as previously demonstrated for NSAIDs in vivo and in vitro (4-8). Several possibilities exist concerning the mechanisms by which aspirin affects stimulussecretion coupling and thereby potentiates PC function. Stimulus-secretion coupling in PC involves multiple second messenger pathways that may act synergistically. These signal transduction sites include either $\mathbf{H}_{2}$ or muscarinic receptors interacting with specific agonists (e.g., histamine and carbachol) which stimulate intracellular cAMP, as regulated by $\mathrm{PGE}_{2}$, or initiate hydrolysis of membrane phospholipids. The former receptor activates cAMP-dependent protein kinase A (PKA) and the latter leads to elevation of cellular $\mathrm{IP}_{3}$ and DAG, which, respectively, mobilizes intracellular $\mathrm{Ca}^{2+}(26)$ and activates PKC (27). Protein kinase activation can phosphorylate intracellular proteins $(28,29)$ and produce multiple effects on PC secretory activity (27). The final step responsible for acid exiting from $\mathrm{PC}$ is via the proton pump, $\mathrm{H}^{+}, \mathrm{K}^{+}$ ATPase.

Aspirin did not appear to involve the $\mathrm{H}_{2}$ receptor or adenylate cyclase/cAMP system since cimetidine failed to block the potentiation of dbcAMP-stimulated AP uptake by aspirin (Fig. 3) and aspirin potentiated forskolin, IBMX- and dbcAMP-stimulated AP uptakes (Fig. 2). These observations support a regulatory role for aspirin in conjunction with secretagogues distal to the site of the catalytic subunit of adenylate cyclase activation. It also appears unlikely that the actions of aspirin were mediated by the stimulatory or inhibitory guanine-nucleotide-binding proteins because aspirin did not affect PC cAMP content (Table I).

Potentiation of secretagogue-stimulated acid secretion by aspirin was dependent on $\left[\mathrm{Ca}^{2+}\right]_{0}$, since aspirin's augmentation of stimulated acid secretion was prevented in a $\mathrm{Ca}^{2+}$-free medium or by pretreatment with the $\mathrm{Ca}^{2+}$ channel blocker $\mathrm{La}^{3+}$ (Fig. 3). The blockade by $\mathrm{La}^{3+}$ of aspirin potentiation of AP uptake (Figs. 3 and 4) can be explained by interfering with a postulated reloading $\mathrm{Ca}^{2+}$ pathway (30), which requires reentry of $\mathrm{Ca}^{2+}$ from the medium into intracellular pools. We have not excluded an effect of aspirin to refill internal $\mathrm{Ca}^{2+}$ stores from the extracellular space via $\mathrm{Ca}^{2+}$ influx through PC plasma membrane $\mathrm{Ca}^{2+}$ channels. However, such channels are unique since verapamil and diltiazem did not change significantly $\left[\mathrm{Ca}^{2+}\right]_{i}$ responses either to secretagogues or to aspirin (unpublished observations).

Aspirin, like secretagogues (Table I), increases $\left[\mathrm{Ca}^{2+}\right]_{i}$ from basal levels but unlike secretagogues, did not concomitantly stimulate basal acid secretion (Fig. 4). The elevation in $\left[\mathrm{Ca}^{2+}\right]_{i}$ induced by carbachol and histamine was blocked by atropine and cimetidine, respectively, as previously described $(11,17)$. In contrast, aspirin-induced release of $\left[\mathrm{Ca}^{2+}\right]_{i}$ was unaffected by atropine or cimetidine alone or together, suggesting an independent nonreceptor-mediated $\mathrm{Ca}^{2+}$ release mechanism. These observations raise questions concerning the source of $\mathrm{Ca}^{2+}$ released by aspirin. Our comparative data between pro- longed EGTA washes, which depleted intracellular $\mathrm{Ca}^{2+}$ and $\left[\mathrm{Ca}^{2+}\right]_{\mathrm{o}}$ (Fig. $5 \mathrm{C}$ ) and a brief EGTA wash, which only depleted $\left[\mathrm{Ca}^{2+}\right]_{0}$ (Fig. $5 \mathrm{D}$ ), indicated that the source of $\mathrm{Ca}^{2+}$ released by aspirin, like secretagogues, was intracellular.

If aspirin-induced $\mathrm{Ca}^{2+}$ release was from an intracellular source, one would expect a mechanism involving inositol lipid hydrolysis with generation of $\mathrm{IP}_{3}$. In nonexcitable tissue $\mathrm{IP}_{3}$ sensitive $\mathrm{Ca}^{2+}$ release from the calcisome has been postulated (31). In our study it appears that, unlike carbachol, intracellular $\mathrm{Ca}^{2+}$ was derived from sources insensitive to $\mathrm{IP}_{3}$ since aspirin and histamine failed to increase inositol phosphates turnover (Table I). Aspirin may induce alternative pathways for mobilizing $\left[\mathrm{Ca}^{2+}\right]_{i}$ and interact with separate cytosolic, membrane-associated and/or mitochondrial $\mathrm{Ca}^{2+}$ pools. Support for an $\mathrm{IP}_{3}$-independent pathway using various agents to mobilize $\left[\mathrm{Ca}^{2+}\right]_{i}$ has been reported in vascular smooth muscle $(32,33)$, pancreatic islets (34), T lymphocytes (35), and sea urchin eggs (36). Although these reported intracellular products may be messengers for mobilizing $\left[\mathrm{Ca}^{2+}\right]_{i}$, our data cannot exclude the possibility that $\mathrm{IP}_{3}$ was unmeasurable because it was too rapidly degraded or was compartmentalized into cellular pools too small to be detected.

It is of interest to note that aspirin failed to potentiate carbachol-stimulated AP uptake (Fig. 2). It is therefore possible that the maximal increase in $\left[\mathrm{Ca}^{2+}\right]_{i}$ induced by carbachol could have prevented further intracellular release of $\mathrm{Ca}^{2+}$ and thereby no potentiation of AP accumulation by aspirin (Fig. 2). In contrast to carbachol, aspirin potentiated histamine-, forskolin-, IBMX-, and dbcAMP-stimulated acid secretion. All of the aforementioned secretogogues, except dbcAMP, augmented $\left[\mathrm{Ca}^{2+}\right]_{i}$. These findings suggest that enhancement of acid secretion by aspirin may involve both $\mathrm{Ca}^{2+}$-dependent and $\mathrm{Ca}^{2+}$-independent pathways. This concept is, in part, consistent with the observations of Negulescu and Machen (11) in single perfused PC showing that both histamine and dbcAMP (+IBMX in their system) increased acid secretion while histamine, but not dbcAMP, increased $\left[\mathrm{Ca}^{2+}\right]_{i}$.

The relationship between aspirin-induced $\mathrm{Ca}^{2+}$ flux, which occurs within seconds and augmentation of secretagogue-stimulated acid secretion, which can be measured within $15 \mathrm{~min}$ (Fig. 4), is still circumstantial. Since calcium is known to play a central role in the regulation of gastric acid secretion, irrespective of the type of stimulation, the correlation between aspirin potentiation of secretagogue-stimulated acid secretion with changes in $\left[\mathrm{Ca}^{2+}\right]_{\mathrm{i}}$ suggests that both effects may be related. There is a latent period between the $\mathrm{Ca}^{2+}$ signal and secretory responses in PC postulated to reflect various intracellular events such as morphological transformation and ion pumping by $\mathrm{H}^{+}, \mathrm{K}^{+}$-ATPase.

Aspirin is a strong cyclooxygenase inhibitor and reduced $\mathrm{PGE}_{2}$ content in $\mathrm{PC}$ by $98 \%$ (Fig. 7). The decrease in $\mathrm{PGE}_{2}$ levels induced by aspirin could augment acid secretion in PC as we observed in the chambered frog gastric mucosa (37) and for indomethacin in vivo (5). However, in PC basal acid secretion was unaffected by this degree of reduction in $\mathrm{PGE}_{2}$ levels. Histamine-stimulated acid secretion is inhibited by exogenous $\mathrm{PGE}_{2}(16,38)$ without altering acetylcholine or gastrin-stimulated acid secretion (38). Therefore, we examined whether aspirin's potentiation of histamine- and dbcAMP-stimulated AP uptakes could be ameliorated by exogenous dmPGE 2 . Such treatment inhibited by $\sim 30 \%$ the acid response to histamine alone and its potentiation by aspirin to the same ex- 
tent. However, dbcAMP-stimulated AP uptake was augmented by dmPGE 2 to the same level as with dbcAMP + aspirin, suggesting prevention of the aspirin-potentiating effect. Soll (38) also found that $\mathrm{PGE}_{2}$ increased dbcAMP + gastrin-stimulated AP uptake. The effects of aspirin on prestimulated secretion could be mediated by its ability to inhibit $\mathrm{PGE}_{2}$ generation, since $\mathrm{dmPGE}_{2}$ prevented aspirin-induced potentiation of secretagogue-stimulated acid secretion (Fig. 8).

It is unlikely that any one mechanism is entirely responsible for the aspirin-induced enhancement of prestimulated acid secretion. We postulate that aspirin interacted at a site(s) beyond adenylate cyclase and before $\mathrm{H}^{+}, \mathrm{K}^{+}$-ATPase as supported by our data showing that potentiation of secretagoguestimulated acid secretion by aspirin did not further enhance intracellular cAMP and aspirin did not activate $\mathrm{H}^{+}, \mathrm{K}^{+}$-ATPase. Our measurements of inositol phosphates turnover suggests that aspirin releases $\mathrm{Ca}^{2+}$ from $\mathrm{IP}_{3}$-independent intracellular storage pools. Moreover, a protein kinase inhibitor, isoquinolinylsulfonamide, previously reported to augment secretagogue-stimulated acid secretion in PC $(39,40)$, mimicked the potentiating effects of aspirin on histamine- and dbcAMP-stimulated acid secretion (unpublished observations). These observations implicate involvement of PKA or PKC in the potentiation of secretagogue-stimulated acid secretion. Further evidence is necessary before conclusions can be made regarding the site(s) of action of aspirin in PC.

The proposed mobilization of $\mathrm{Ca}^{2+}$ in $\mathrm{PC}$ by aspirin and its subsequent augmentation of stimulated acid secretion may, in part, underlie the pathogenesis of aspirin-induced gastric mucosal injury. While decreased mucosal prostanoid synthesis may play a contributory role in the mechanism of NSAIDsinduced gastric damage $(41,42)$, recent evidence questions the strict relationships between the development of mucosal injury, enhanced gastric acid secretion and inhibition of prostaglandin production (43-48).

\section{Acknowledgments}

We thank T. Berglindh, J. R. Goldenring, and J. DelValle for stimulating discussion and helpful suggestions.

\section{References}

1. Soll, A. F., J. Kurata, and J. E. McGuigan. 1989. Ulcers, nonsteroidal antiinflammatory drugs, and related matters. Gastroenterology. 96:561-568.

2. Lanza, F. L. 1984. Endoscopic studies of gastric and duodenal injury after use of ibuprofen, aspirin, and other nonsteroidal antiinflammatory drugs. Am. J. Med. 1A:19-24.

3. Levy, M., D. R. Miller, D. W. Kaufman, V. Siskind, P. Schwingl, L. Rosenberg, B. Strom, and S. Shapiro. 1988. Major upper gastrointestinal tract bleeding: relation to the use of aspirin and other non-narcotic analgesics. Arch. Intern. Med. 148:281-285.

4. Schwartzel, E. H., Jr., R. A. Levine, S. E. Schwartz, and C. E. Ganley. 1984. Indomethacin enhances histamine-stimulated acid production in rabbit isolated fundic glands. Prostaglandins Leukotrienes Med. 14:383-390.

5. Levine, R. A., and E. H. Schwartzel, Jr. 1984. Effect of indomethacin on basal and histamine-stimulated human gastric acid secretion. Gut. 25:718-722.

6. Gerkins, J. F., D. G. Shand, C. Flexner, A. S. Nies, J. A. Oates, and J. L. Data. 1977. Effect of indomethacin and aspirin on gastric blood flow and acid secretion. J. Pharmacol. Exp. Ther. 203:646:652.
7. Hunt, J. N., J. L. Smith, C. L. Jiang, and L. Kessler. 1983. Effect of synthetic prostaglandin $E_{1}$ analog on aspirin-induced gastric bleeding and secretion. Dig. Dis. Sci. 28:897-902.

8. Reeves, J. J., and R. Stable. 1985. Effects of indomethacin, piroxican and selected prostanoids on gastric acid secretion by the rat isolated gastric mucosa. Br. J. Pharmacol. 86:677-684.

9. Wolfe, M. M., and A. H. Soll. 1988. Physiology of gastric acid secretion. N. Engl. J. Med. 319-1707-1715.

10. Bertaccini, G., and G. Coruzzi. 1988. Regulation of receptors on parietal cells and acid secretion. Scand. J. Gastroenterol. 23 (Suppl 146):22-31.

11. Negulescu, P. A., and T. E. Machen. 1988. Intracellular $\mathrm{Ca}^{2+}$ regulation during secretagogue stimulation of the parietal cell. Am. J. Physiol. 254:C130-C140.

12. Chew, C. S. 1986. Cholecystokin, carbachol, gastrin, histamine, and forskolin increase $\left[\mathrm{Ca}^{2+}\right]_{\mathrm{i}}$ in gastric glands. Am. J. Physiol. 250:G814-G823.

13. Berglindh, T., and N. J. Obrink. 1976. A method for preparing isolated glands from the rabbit gastric mucosa. Acta Physiol. Scand. 96:150-159.

14. Berglindh, T. 1985. Improved one-step purification of isolated gastric parietal cells from rabbit and dog. Fed. Proc. 44:616a. [Abstr.]

15. Mazzeo, A. R., J. Nandi, and R. A. Levine. 1988. Effects of ethanol on parietal cell membrane phospholipids and proton pump function. Am. J. Physiol. 254:G57-G64.

16. Levine, R. A., K. R. Kohen, E. H. Schwartzel, Jr., and C. E. Ramsay. 1982. $\mathrm{PGE}_{2}$-histamine interactions on cAMP, cGMP and acid production in isolated fundic glands. Am. J. Physiol. 242:G21G26.

17. Malinowska, D. H., G. Sachs, and J. Cuppoletti. 1988. Gastric $\mathrm{H}^{+}$secretion: histamine (cAMP-mediated) activation of protein phosphorylation. Biochim. Biophys. Acta. 972:95-109.

18. Grynkiewicz, G., M. Poenie, and R. Y. Tsien. 1985. A new generation of $\mathrm{Ca}^{2+}$ indicators with greatly improved fluorescence properties. J. Biol. Chem. 260:3440-3450.

19. Tsien, R. Y., T. J. Rink, and M. Poenie. 1985. Measurement of cytosolic free $\mathrm{Ca}$ in individual small cells using fluorescence microscopy with dual excitation wavelengths. Cell Calcium. 6:145-157.

20. Schwartzel, E. H., Jr., S. Bachman, and R. A. Levine. 1977. Cyclic nucleotide activity in gastrointestinal tissues and fluids. Anal. Biochem. 78:395-405.

21. Chiba, T., S. K. Fisher, J. Park, E. B. Sequin, B. W. Agranoff, and T. Yamada. 1988. Carbamoylcholine and gastrin induced inositol lipid turnover in canine gastric parietal cells. Am. J. Physiol. 255:G99-G105.

22. Berridge, M. J., M. C. Dawson, C. P. Downes, J. P. Heslop, and R. F. Irvine. 1983. Changes in the levels of inositol phosphates after agonist-dependent hydrolysis of membrane phosphoinositides. Biochem. J. 212:473-482.

23. Nandi, J., Z. Meng-Ai, and T. K. Ray. 1987. Purification and partial characterization of $\left(\mathrm{H}^{+}, \mathrm{K}^{+}\right)$-transporting adenosinetriphosphatase from fundic mucosa. Biochemistry. 26:4264-4272.

24. Wallace, J. L., and M. M. Cohen. 1984. Gastric mucosal protection with chronic mild restraint: role of endogenous prostaglandins. Am. J. Physiol. 247:G127-G132.

25. Bredt, D. S., R. J. Moursy, and S. H. Snyder. 1989. A simple, sensitive, and specific radioreceptor assay for inositol 1,4,5-triphosphate in biological tissues. Biochem. Biophys. Res. Commun. 159:976-982.

26. Tsunoda, Y., H. Takeda, M. Asaka, I. Nakagaki, and S. Susaki. 1988. Initial and sustained calcium mobilization in the parietal cell during stimulation with gastrin, inositol triphosphate, phorbol ester and exogenous diacylalycerol. FEBS (Fed. Eur. Biochem. Soc.) Lett. 232:83-90.

27. Hatt, J. R., and P. J. Hanson. 1989. Sites of action of protein kinase $\mathrm{C}$ on secretory activity in rat parietal cells. Am. J. Physiol. 256:G129-G138.

28. Chew, C. S., and M. R. Brown. 1987. Histamine increases 
phosphorylation of 27- and 40-KDa parietal cell proteins. Am. J. Physiol. 253:G823-G829.

29. Brown, M. R., and C. S. Chew. 1989. Carbachol-induced protein phosphorylation in parietal cells: regulation by $\left[\mathrm{Ca}^{2+}\right]_{\mathrm{i}} . \mathrm{Am} . J$. Physiol. 257:G99-G110.

30. Muallem, S., C. J. Fimmel, S. J. Pandol, and G. Sachs. 1986. Regulation of free cytosolic $\mathrm{Ca}^{2+}$ in the peptic and parietal cells of the rabbit gastric gland. J. Biol. Chem. 261:2660-2667.

31. Volepe, P., K. H. Krause, S. Hashimoto, F. Zorzato, T. Pozzan, J. Meldolesi, and D. P. Lew. 1988. The "Calcisome", a cytoplasmic organelle; the inositol 1,4,5-triphosphate-sensitive $\mathrm{Ca}^{2+}$ store of nonmuscle cells. Proc. Natl. Acad. Sci. USA. 85:1091-1095.

32. Kobayashi, S., A. V. Somlyo, and A. P. Somlyo. 1988. Heparin inhibits the inositol 1,4,5-triphosphate-dependent but not the independent, calcium release induced by guanine nucleotide in vascular smooth muscle. Biochem. Biophys. Res. Commun. 153:625-631.

33. Tawada, J., K.-I. Furukawa, and M. Shigekawa. 1988. Cyclic AMP enhances inositol trisphosphate-induced mobilization of intracellular $\mathrm{Ca}^{2+}$ in cultured aortic smooth muscle cells. J. Biochem. 104:795-800.

34. Wolf, B. A., J. Turk, W. R. Sherman, and M. L. McDaniel. 1986. Intracellular $\mathrm{Ca}^{2+}$ mobilization by arachidonic acid. Comparison with myo-inositol 1,4,5-triphosphate in isolated pancreatic islets. $J$. Biol. Chem. 260:13496-13501.

35. Ebanks, R., C. Roifman, A. Mellors, and G. B. Mills. 1989. The diacylglycerol analogue, 1,2-sn-dioctanoylglycerol, induces an increase in cytosolic free $\mathrm{Ca}^{2+}$ and cytosolic acidification of $\mathrm{T}$ lymphocytes through a protein kinase $\mathrm{C}$-independent process. Biochem. $J$. 258:689-698.

36. Lee, H. C., T. F. Walseth, G. T. Bratt, R. N. Hayes, and D. L. Clapper. 1988. Structural determination of a cyclic metabolite of $\mathrm{NAD}^{+}$with intracellular Ca-mobilizing activity. J. Biol. Chem. 264:1608-1615.

37. Nandi, J., and R. A. Levine. 1990. Aspirin (ASA) augments prestimulated acid secretion in chambered frog gastric mucosa. Gastroenterology. 98:95a. (Abstr.)

38. Soll, A. 1980. Specific inhibition by prostaglandins $E_{2}$ and $I_{2}$ of histamine-stimulated $\left[{ }^{14} \mathrm{C}\right]$ aminopyrine accumulation and cyclic adenosine monophosphate generation by isolated parietal cells. J. Clin. Invest. 65:1122-1229.

39. Malinowska, D. H. 1988. Role of protein kinase $\mathrm{C}$ in gastric acid secretion. FASEB (Fed. Am. Soc. Exp. Biol.). 3:1150a. [Abstr.]

40. Ostrowski, J., and K. Bomsztyk. 1989. Interaction of signal transduction pathways in mediating acid secretion by rat parietal cells. Am. J. Physiol. 256:C873-C879.

41. Vane, J. R. 1971. Inhibition of prostaglandin synthesis as a mechanism of action for aspirin-like drugs. Nature (Lond.). 231:232235.

42. Rachmilewitz, D., M. Ligumsky, A. Fich, E. Goldin, A. Eliakim, and F. Karmeli. 1986. Role of endogenous gastric prostanoids in pathogenesis and therapy of duodenal ulcer. Gastroenterology. 90:963-969.

43. Levine, R. A., S. Petokas, J. Nandi, and D. Enthoven. 1988. Effects of nonsteroidal, antiinflammatory drugs on gastrointestinal injury and prostanoid generation in healthy volunteers. Dig. Dis. Sci. 33:660-666.

44. Rainsford, K. D. 1988. Comparative irritancy of oxaprozin on the gastrointestinal tract of rats and mice: relationship to drug uptake and effects in vivo on eicosanoid metabolism. Aliment. Pharmacol. Ther. 2:439-450.

45. Goldin, E., R. Stalnikowicz, D. Wengrower, R. Eliakim, A. Fich, M. Ligumsky, F. Karmeli, and D. Rachmilewitz. 1988. No correlation between indomethacin-induced gastroduodenal damage and inhibition of gastric prostanoid synthesis. Aliment. Pharmacol. Ther. 2:369-375.

46. Mogard, M. H., V. Maxwell, T. J. Reedy, and J. H. Walsh. 1987. Gastric acidification inhibits meal-stimulated gastric acid secretion after prostaglandin synthesis inhibition by indomethacin in humans. Gastroenterology. 93:63-68.

47. Redfern, J. S., E. Lee, and M. Feldman. 1987. Effect of indomethacin on gastric mucosal prostaglandins in humans. Gastroenterology. 92:969-977.

48. Cohen, M. M., and W. C. McDonald. 1982. Mechanism of aspirin injury to human gastroduodenal mucosa. Prostaglandins Leukotrienes Med. 9:241-255. 